Cornell Law Library

Scholarship@Cornell Law: A Digital Repository

Cornell Law Faculty Publications

4-27-2007

\title{
Legal Information Management in a Global and Digital Age: Revolution and Tradition
}

Claire M. Germain

CornellLawSchool, cmg13@cornell.edu

Follow this and additional works at: http://scholarship.law.cornell.edu/lsrp_papers

Part of the Legal Writing and Research Commons

\section{Recommended Citation}

Germain, Claire M., "Legal Information Management in a Global and Digital Age: Revolution and Tradition" (2007). Cornell Law Faculty Publications. Paper 73.

http://scholarship.law.cornell.edu/lsrp_papers/73

This Article is brought to you for free and open access by Scholarship@Cornell Law: A Digital Repository. It has been accepted for inclusion in Cornell Law Faculty Publications by an authorized administrator of Scholarship@Cornell Law: A Digital Repository. For more information, please contact jmp8@cornell.edu. 


\title{
CORNELL LAW SCHOOL
}

\section{Legal StUdies Research PAPER SeRIES}

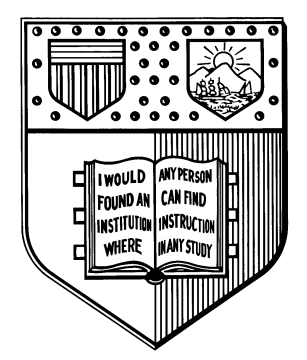

\section{Legal Information Management in a Global and Digital Age: Revolution and Tradition}

\author{
Claire M. Germain
}

\author{
Cornell Law School \\ Myron Taylor Hall \\ Ithaca, NY 14853-4901
}

Cornell Law School research paper No. 07-005

This paper can be downloaded without charge from:

The Social Science Research Network Electronic Paper Collection:

http://ssrn.com/abstract=983197 


\title{
Legal Information Management in a Global and Digital Age: Revolution and Tradition
}

\author{
Claire M. Germain*
}

\begin{abstract}
This article presents an overview of the public policy issues surrounding digital libraries, and describes some current trends, such as Web 2.0, the social network. It discusses the impact of globalization and the Internet on international and foreign law information, the free access to law movement and open access scholarship, and mass digitization projects, then turns to some concerns, focusing on preservation and long term access to born digital legal information and authentication of official digital legal information It finally discusses new roles for librarians, called upon to evaluate the quality of information; teach legal research methodology; and be advocates in information policy. Law librarians are encouraged to join professional associations and undergo continuous professional education. A recent development in the U.S.A., to add a legal research test on the bar exam, is of interest to the whole world, because it signifies the importance of a sound legal research training to the competent practice of law.
\end{abstract}

\section{INTRODUCTION}

I. Transformation of Legal Information

Internet and Globalization

Information Overload and Web 2.0

Free Access to Law and Open Access Scholarship

Mass Digitization Projects

II. Taking a Critical Look

Impact on Legal Research

Preservation of Born Digital Information

Authenticity of Official Legal Information

III. New Roles for Law Librarians

Evaluators of Quality of Information

Teachers of Legal Research

Core Participants in the Mission of their Institutions

Advocates for Free Access through Global Networks

CONCLUSION

* CClaire M. Germain, 2007. Edward Cornell Law Librarian \& Professor of Law. Cornell Law School. Ithaca, N.Y./U.S.A. cmg13@cornell.edu. This article is an expanded version of the keynote address delivered at the invitation of Chief Justice Ellen Gracie Northfleet, at the $1^{\text {st }}$ Seminar on Juridical Information Management in Digital Environments, Brasilia, Brazil, Monday, February 12, 2007. I wish to thank Matt Morrison, Research Attorney, Cornell Law Library, for providing useful references, and the expert staff of Cornell Law Library, for their thoughtful remarks on this article at various stages. 


\section{INTRODUCTION}

Blogosphere, folksonomy, the long tail, mashups, social bookmarking, tagging, filters, information architecture, podcasting, harvesting web content. These terms do not evoke the familiar library we are used to, but they have entered our daily lives as librarians. Times have changed drastically, and the information revolution is underway. This article presents an overview of the public policy issues surrounding digital libraries in the law field, and describes some current trends, such as Web 2.0, the social network. It discusses the free access to law movement, and mass digitization projects, then turns to some concerns, focusing on preservation and long term access to born digital legal information, and authentication of official digital legal information. It finally discusses new roles for law librarians. Many articles on information management are written from the information technology angle, but this article is written from the legal information specialist's perspective. Librarians' specific skills are to organize information and build collections. How do we cope with digital libraries and integrate the traditional library and methods with the new Internet-centered information landscape, how do we embrace the new world, with its own terminology, information access and delivery mechanisms, and not lose track of quality information, teach the proper research methodology, and find reliable and precise information? How do we meet the expectations of researchers, considering their information seeking behaviors?

\section{Transformation of Legal Information}

My interest and expertise with legal information management is based on my own background and professional experience in two large academic law libraries in the United States, and my training as a lawyer from the civil law and common law traditions. I have been the witness to the profound transformation in access to information and law libraries. In my current position at Cornell Law School, in Ithaca, New York, U.S.A. I am a librarian and a law professor. ${ }^{1} \mathrm{I}$ am actively involved in all aspects of legal information, from rare books to cyberspace, particularly the digital law issues, and the preservation and long term access to born digital legal information. I have been active in the American Association of Law Libraries, having served as President in 2005-06. ${ }^{2}$ My teaching and scholarly interests include foreign and international law and legal research. I teach a seminar in French law at Cornell, and during our Cornell Law School Summer Institute in Paris, and I have taught many legal research courses to first-years and upperclass students. I have taught classes on the use of the Internet for legal research, in the U.S.A., Paris, France, and Barcelona, Spain. I frequently speak on comparative law and legal research topics in the United States, Europe, Canada, and most recently Brazil.

\footnotetext{
${ }^{1}$ My Curriculum Vitae and publications can be found at www.lawschool.cornell.edu/faculty.

${ }^{2}$ AALL has over 5,000 members, who work as law librarians in law firms, law schools, courts, corporations, government offices, or as solo practitioners. For more information, see www.aall.org.
} 


\section{A. Internet and Globalization}

The two key forces having a deep impact on society are uniformly recognized as being the Internet, leading to the digital revolution, and the globalization, with its deep impact on legal information. These two forces can be studied separately, but they are intrinsically interwoven into the work of law librarians and access to legal information. The Internet and digital revolution have led both to an information overload, with information coming from many different directions, and the simultaneous increased speed of information, where almost instantaneous responses are expected from the easy flow of information. The context of legal research today presents us with an inflation of information, augmented by an inflation of legal issues. Law reflects societal concerns, and new areas of regulation have appeared, as well as new substantive law areas.

Environmental law, bio-ethics, information technology and Internet-related issues are just a few. These new areas appear in a domestic context. In addition, almost every domestic law area now has an international component.

Globalization ${ }^{3}$ has been defined as the process of integrating nations and peoples-politically, economically, and culturally-into a larger community. The focus is not on nations but on the entire globe. ${ }^{4}$ This complex, controversial, and synergistic process combines technology in communications and transportation with the deregulation of markets and open borders to lead to vastly expanded flows of people, money, goods, services, and information. ${ }^{5}$ The dark side of globalization produces economic and social dislocations and arouses public concerns over job security, concentration of economic power, harm to the environment, danger to public health and safety and the disintegration of indigenous cultures. ${ }^{6}$ In the information field, we can also say that it has created a digital divide, between those who have access to the Internet, and those who do not. The globalization phenomenon has had a deep impact on the legal profession, ${ }^{7}$ legal

\footnotetext{
${ }^{3}$ The globalization phenomenon has been covered extensively in the literature. For short, recent books, see Alex MacGillivray, A Brief History of Globalization: the Untold Story of our Incredible Shrinking Planet (2006); and Manfred Steger, Globalization: A Very Short Introduction (2003).

${ }^{4}$ See the definition in Encyclopedia of American Foreign Policy (2002 ).

${ }^{5} I d$.

${ }^{6} I d$.

${ }^{7}$ The Symposium Issue of 14 Indiana Journal of Global Legal Studies (forthcoming 2007) focuses on how globalization is fundamentally changing the work lives and professional opportunities of lawyers in the U.S. and abroad, and explores various interrelated themes, such as law firm strategy, the relevance of geography, the lawmaking role of transnational lawyers, and how cultural norms affect or shape our perceptions of ethical lawyering.
} 
education, ${ }^{8}$ and in turn, on the law librarian profession ${ }^{9}$ and the legal literature. The world is shrinking, and it is now difficult to distinguish between domestic and foreign and international law in a global setting. We need to look beyond national jurisdiction. New terms have been coined, such as Transnational law, ${ }^{10}$ Global law, and there is an international element to most domestic law subjects, e.g. international trade law, the international law of human rights, environment, criminal law, etc. The law of foreign countries has to be studied. Every important domestic subject -securities regulation, criminal law, procedure, environmental law, family law, etc.- - has an international dimension. The U.S. Supreme Court has taken foreign and international law into consideration in several decisions. ${ }^{11}$ Interestingly, comments on hot topics like the famous debate between U.S. Justices Breyer and Scalia on the use of foreign law by U.S. courts, often take the form of blogs. ${ }^{12}$

Globalization has permeated and deeply influenced the legal literature. There has been an explosion in the legal literature in international and foreign law, which is well documented in indexes and catalogs. I have observed it personally over the years. My career has been affected in a deep way by the many changes in the legal information environment. I did much of my professional career in legal information in the print world, and I evolved as the world of legal information started to change, first in an evolution, and now as a revolution. I started my career as a law graduate from France and the United States, ${ }^{13}$ following studies in Germany and a university degree in

\footnotetext{
${ }^{8}$ For contributions from the U.S.A., Canada, and Europe, see "Globalizing Legal Education--Symposium Educating Lawyers for Transnational Challenge," 23 Penn St. Int'l L. Rev. 753 (2005); Wesley Pue, "Globalization and Legal Education: Views from the Outside-In,”, 81 International Journal of the Legal Profession 87-102 (2001); Jens Drolshammer, The Effects of Globalization on Legal Education - An Agenda from a European Perspective for the Interdisciplinary Training of a New International Commercial Lawyer, 2003.

9 See Ruth Bird, "A Moveable Feast - Law Librarianship in the Noughties" (December 2006). Oxford Legal Studies Research Paper No. 52/2006 Available at SSRN, papers.ssrn.com/sol3/papers.cfm?abstract_id=951080

${ }^{10}$ The history of the term "transnational” is retraced in Germain's Transnational Law Research Ch. I, section 1.01.3 (1991- . Looseleaf). The term is often attributed to Philip Jessup in his book Transnational Law (1956), but the first author to use it was actually Gustav Walker, an Austrian law professor, in 1934, and then Ernst Rabel in The Conflict of Laws: A Comparative Study (1945).

${ }^{11}$ See Sir Basil Markesinis, Judicial Recourse to Foreign Law: A New Source of Inspiration? (2006); On the debate in the U.S.A., see Sir Basil Markesinis, "National Sufficiency or Intellectual Arrogance? The Current Attitude of American Courts towards Foreign Law, “ 65 Cambridge Law Journal 301 (2006); "Symposium: “Outsourcing Authority?” Citation to Foreign Court Precedent in Domestic Jurisprudence: Aristotle, Cicero and Cardozo: A Perpective on External Law,” 69 Alb. L. Rev. 645 (2006).

${ }^{12}$ See, for instance, Michael C. Dorf, “The Use of Foreign Law in American Constitutional Interpretation: A Revealing Colloquy Between Justices Scalia and Breyer,” http://writ.findlaw.com/dorf/20050119.html (Jan. 19, 2005).

${ }^{13}$ University of Paris XII, France, and Louisiana State University Law School, U.S.A..
} 
German. After receiving a Master's in Law Librarianship from the University of Denver, I started my professional career at Duke Law School as a reference librarian, totally in the print world. During my time at Duke, the first word processors came into being (no more retyping drafts on a type writer), and the first Lexis and then Westlaw dedicated terminals were introduced into the law school. It is during those early years that I wrote Germain's Transnational Law Research: A Guide for Attorneys, the first comprehensive guide devoted to international and foreign law research. ${ }^{14}$ The first edition came out in 1991, a few years before the eruption of the Internet on the scene. My book is published in looseleaf, and was regularly updated. In one of the updates, in 1995, I decided to add a section to each subject and country, devoted to Internet Sources. I am currently preparing a softcover edition, focusing on the most current and useful materials, with a totally different research methodology. Instead of starting with books, the Guide will start with how to do research on the Internet. In sum, the research methodology has been turned upside down. But, it does not mean that the Internet will be the sole source of information. On the contrary, the book purports to show the rich and essential literature beyond the Internet and online sources. Needless to say, however, there will be an online edition of the softcover guide, and possibly a blog or web site to keep it up to date in between editions.

Among the new growing literature worldwide, one can note the growth of textbooks explaining U.S. law to international law students, and introductory books explaining foreign law to researchers from a different country or legal tradition. ${ }^{15}$ There are many such titles, such as comparative law textbooks and casebooks, and many new books on specialized areas of comparative law, rather than books general in scope (e.g., comparative contract and tort law, ${ }^{16}$ constitutional law, environmental law, etc.). A new online service, International Law in Domestic Courts ${ }^{17}$ is emblematic of the transnational law trend. The publishers send out reporters in many countries of the world, who suggest cases, and write annotations on the cases selected. This service provides great empirical data on how national judges apply international law norms.

\footnotetext{
${ }^{14}$ Ardsley on Hudson: Transnational, 1991- Looseleaf. Joseph Andrews Award Winner, 1992.

${ }^{15}$ A small sampling: Kenneth L. Port \& Gerald Paul McAlinn. Comparative Law : Law and the Legal Process in Japan. Durham, N.C.: Carolina Academic Press, 2003. Herbert Hausmaninger. The Austrian Legal System . 2d ed. The Hague ; Boston : Kluwer Law International ; Wien: Manz, 2000. George P. Fletcher and Steve Sheppard. American Law in a Global Context. Oxford ; New York : Oxford University Press, 2005.

${ }^{16}$ Sir Basil Markesinis, QC, Hannes Unberath \& Angus Johnston. The German Law of Contract : A Comparative Treatise. 2d ed. Oxford; Portland, Or.: Hart, 2006; Sir Basil Markesinis, QC. \& Hannes Unberath. The German Law of Torts: A Comparative Treatise. 4th ed. Oxford; Portland, Or.: Hart, 2002.

${ }^{17}$ Oxford University Press. International Law in Domestic Courts (ILDC) is described as an online database containing domestic cases in international law from over 65 jurisdictions, featuring the full-text of judgments in their original language, translations of key passages of non-English judgments into English, and expert commentary, going back to 2000. Users may sign up for e-mail case alerts.
} 


\section{B. Information Overload and Web 2.0}

We find ourselves now swamped with information, an overload which begs for analysis and summary. Technology and the Internet have also changed many things, for instance, we hear about breaking news faster through the Internet than the daily newspapers, or even TV channels, all because of the new information accessibility and immediacy for millions of people around the world. The dilemma we are facing in coping with this torrent of information and data, is who to turn to. According to Peter Nicholson and others, increasingly the answer is - "Well, to ourselves of course, as individuals empowered by a world wide web that has rapidly evolved into a social medium." 18 This medium today supports massively distributed collaboration on a global scale. Web 2.0 was first mentioned in 1999, and popularized by Dale Dougherty, O’Reilly Company in 2004. ${ }^{19}$ It refers to the second generation Internet going from a collection of websites to a platform of services. It is built around social networking, collaboration, and sharing among users. ${ }^{20}$ A big change is an evolution from the use of a stand alone PC to the use of a network. ${ }^{21}$ The principles of Web 2.0 are that it is a platform of services, not just a collection of links, and that users become co-developers of applications. $^{22}$ It takes advantage of the "collective intelligence," with always evolving interfaces. The software frees itself from PC and moves toward PDAs, mobiles, etc. A few major applications, which start spontaneously and, if successful, are then acquired by companies, include Wikis, Podcasting, Blogs , RSS, Wikipedia, Flickr shared pictures (bought by Yahoo), Youtube online video platform (bought by Google); MySpace social network, Customized personal page, aggregates emails, collaborative search engines, etc. The advantages of Web 2.0 are its simplicity, and personalization, its drawbacks include the lack of perennity, reliability, and questions about provenance.

Some of these technologies may be useful for some libraries, and others may not. They present interesting solutions to information overload, and alternative information delivery mechanisms. Some will become killer applications, while others will disappear,

\footnotetext{
${ }^{18}$ Peter Nicholson, “The Changing Nature of Intellectual Authority,” the author is currently President, Council of Canadian Academics. www.arl.org/arl/proceedings/148/

${ }^{19}$ http://www.infotoday.com/IL2007/CallforSpeakers.shtml

${ }^{20}$ The definition proposed by Tim O'Reilly is: "Web 2.0 is the business revolution in the computer industry caused by the move to the Internet as platform, and an attempt to understand the rules for success on that new platform. Chief among those rules is this: build applications that harness network effects to get better the more people use them. (This is what I've elsewhere called "harnessing collective intelligence.")" http://radar.oreilly.com/archives/2006/12/web_20_compact.html

${ }^{21}$ Tom Storey, "Moving to the Network Level,” Next Space: the OCLC Newsletter (No. 4, 2006) http://www.oclc.org/nextspace/004/1.htm

${ }^{22}$ http://www.oreillynet.com/pub/a/oreilly/tim/news/2005/09/30/what-is-web-20.html
} 
or morph into other applications. New ones pop up almost every day. They can improve library services to users or create brand new services to reach users in new ways. Some applications used in law libraries are described below.

\section{Law Blogs}

A blog (the word is derived from web log) is a web site made up of posts that are arranged chronologically, and are archived by date and category. A blawg is a Blog on the law. Blogs have evolved from a starting point with little organization or structure to a whole taxonomy of specialized blogs in different areas, written by different legal professionals. Lawyers write on their areas of expertise, law students, law commentators, and law professors particularly like to create and participate in blogs, and list them on their law school web sites as part of their professional activities. Some even use blogs for teaching, with a law professor using a blog rather than a casebook to teach a class on the death penalty ${ }^{23}$ Blogs have become useful updating services for various legal specialties, keeping law professionals immediately up to date on developments and issues in their areas of practice. Blogs have acquired a certain status, being cited by court decisions, also by law reviews. In march 2007, there were some 51 blogs on law libraries and research (probably mostly from the English language world). ${ }^{24}$

\section{Collaborative Encyclopaedias}

Wikipedia is the best example of a collaborative encyclopaedia, where everyone can freely contribute and edit, and is based on the wiki technology. It is one of the most visited web sites worldwide. ${ }^{25}$ As of early 2007, it contained over 6 million articles in 250 languages. ${ }^{26}$ The notion of collective intelligence has generated much commentary and controversy, alternatively called the "wisdom of crowds" by James Surowiecki, ${ }^{27}$ or the "kingdom of idiots" by the philosopher Norbert Bolz. ${ }^{28}$ One of the co-founders, Larry Sanger, even left the company and created its own moderated collaborative

\footnotetext{
${ }^{23}$ Professor Douglas A. Berman, Ohio State Law School, Columbus, Ohio, U.S.A., http://lsi.typepad.com/death_penalty_moritz/.

${ }^{24}$ Several web sites have by now categorized blogs. For instance, http://www.blawg.com/, with a special focus on law blogs. Several law library blogs are of interest, e.g., http://lawprofessors.typepad.com/law_librarian_blog/ and in Canada, Slaw is a co-operative weblog about Canadian legal research and IT. www.slaw.ca/

${ }^{25}$ See ranking in http://www.alexa.com/

${ }^{26}$ http://ig.wikipedia.org/wiki/Wikipedia

${ }^{27}$ The Wisdom of Crowds: Why the Many Are Smarter Than the Few and How Collective Wisdom Shapes Business, Economies, Societies and Nations. Random House, 2004.

${ }^{28}$ See English translation of an interview published in Der Spiegel in 2006, at http://www.indymedia.org.uk/en/regions/world/2006/08/347557.html
} 
encyclopaedia, Citizendium, which is peer-reviewed. ${ }^{29}$ It is nevertheless the case that Wikipedia is hugely successful, and that U.S courts cite to Wikipedia. ${ }^{30}$ (But see later on the problems posed by court citations to web sites which no longer exist). Another notable example is Jurispedia, which is moderated. ${ }^{31}$

\section{RSS (Really Simple Syndication)}

RSS is a syndication format developed by Netscape in 1999, which has become very popular for aggregating updates to blogs and news sites. RSS has also stood for "Rich Site Summary" and "RDF Site Summary." ${ }^{32}$ RSS presents an alternative delivery platform because the user gets only relevant content, is notified automatically when new content arrives, and is not required to learn new technologies. The user can decide which content to subscribe to automatically, from the millions of blogs, news services, and content providers which offer RSS feeds.

\section{Free Access to Law Movement and Governmental Policies}

In many countries of the world, official documents are now available on the Internet, based on the policy of governments to provide better access to legal information for the public. The Internet has thus greatly facilitated worldwide access to legal information. These efforts are proceeding at the national level, in many countries, ${ }^{33}$ and at the regional level, e.g., the European Union, ${ }^{34}$ and international level, e.g. the United Nations, World Intellectual Property Organization (WIPO), International Labor

\footnotetext{
${ }^{29}$ http://www.larrysanger.org/

${ }^{30}$ Noam Cohen, "Courts Turn to Wikipedia, but Selectively," New York Times 3 (January 29, 2007, Section C)

${ }^{31}$ http://www.jurispedia.org/. A Wiki type portal, JurisPedia is an encyclopaedic project of academic
} initiative devoted to worldwide law, legal and political sciences. Its objective is to create a universal legal encyclopedia. Jurispedia has developed on the initiative of Équipe de Recherche Informatique et Droit (Faculty of Law of the University of Montpellier I , the Faculty of Law of the University of Can Tho, the Faculty of Law of the University of Groningen , the Institute for Law and Informatics (Saarland University) and the team of JURIS (Université du Québec à Montréal). The project is open for cooperation with other partners.

32 http://www.pcmag.com/encyclopedia_term/0,2542,t=RSS\&i=50680,00.asp

${ }^{33}$ As examples, the two major French official government portals are Legifrance (http://www.legifrance.gouv.fr/) and Service Public (http://www.service-public.fr/), the citizens' guide to law and administration. In the U.S.A., usa.gov (GobiernoU.S.A..gov is the Spanish version) is the official portal of the U.S. government to find all federal, state, local government information and services..

${ }^{34}$ www.europa.eu. The European Union official portal comprehensively covers news and information about its activities, institutions, policies and programs, including full texts of official documents. 
Organization (ILO), and International Court of Justice (ICJ), to name a few. ${ }^{35}$ These official portals contain an amazing, and ever growing, amount of authoritative information. Universities are also helping with efforts to create linkages, and interconnected global networks. A particular successful venture has resulted in the creation of legal information institutes in different parts of the world. The World Legal Information Institute ${ }^{36}$ currently comprises 686 databases from 86 countries including 21 international databases in collaboration with members of the Free Access to Law Movement. That movement advocates for those who value free access to law, and realize the fact that most countries still do not have effective facilities for free access to law. The free access to law movement, centered around university-based legal information institutes, is assisting and encouraging the development of free access law facilities in many countries in the developing world. While doing so, it is also creating a global network of interconnected free-access legal research facilities on the Internet. ${ }^{37}$ The world legal information institutes include Australasia (AustLII), UK \& Ireland BAILII), Canada (CanLII), The Commonwealth (CommonLII), Cyprus (CyLaw), Droit Francophone, Hong Kong (HKLII), JuriBurkina, New Zealand (NZLII), Pacific Islands (PacLII), Southern Africa (SAFLII), and U.S.A. (LII(Cornell)). ${ }^{38}$

In the United States, because of the American principle that citizens should have free access to government information, most federal and state publications are in the public domain, without being subject to copyright, and many official texts and documents are now available on the Internet free of charge. Today, most current U.S. legislative, regulatory, and case law texts are available from federal and state government web sites, and steadily expanding.

\footnotetext{
35 www.wipo.org; www.ilo.org; www.icj-cij.org/. Cornell Law School collaborated in the start of some of these web sites. Cornell Law Library helped create the first web site of the International Court of Justice, after a visit at the ICJ in the Hague in the summer of 1996. Jay Greco, JD’ 98 spent a summer at the Court and provided advice, and then did the same thing for the ILO, in Geneva, Switzerland. The then ILO webmaster in turn visited Cornell. Cornell Law Library subsequently created mirror sites for the ICJ and the ILO web sites, for redundancy. It was helpful when too many requests went to the host website. "Web Mirror Sites: Creating the Research Library of the Future, and More...," in Law Library Collection Development in the Digital Age 87-104 (Binghamton, NY: Haworth Information Press, Michael Chiorazzi and Gordon Russell, eds. 2002) (co-published simultaneously as 21 Legal Reference Services Quarterly Nos. 2-4 (2002).

${ }^{36}$ http://www.worldlii.org/

${ }^{37}$ Graham Greenleaf, Philip Chung and Andrew Mowbray, "Emerging Global Networks for Free Access to Law: WorldLII’s Strategies,” 1 Journal of Electronic Resources in Law Libraries (forthcoming 2007).
}

\footnotetext{
38 The Legal Information Institute was the pioneer in these efforts and inspired the creation of other institutes. It started at Cornell Law School in 1993, under the leadership of Professor Peter Martin and Research Associate Thomas Bruce. www.law.cornell.edu
} 


\section{Open Access Legal Scholarship}

Open access is the electronic publication of scholarly work that is available for free without copyright constraints other than attribution, and where the author keeps the copyright. $^{39}$ The movement has arisen in the scientific field because of the high cost of print and electronic publications and the search for an alternative form of publication. In the United States, the problem is less acute, because most academic law journals are student edited law reviews, with a strong learning component for students. They are subsidized by the law schools, and cost about $\$ 50$ per year or less. In an interesting recent development, some law reviews are now adding a blog or online component to their regular issues. ${ }^{40}$

Because of the Internet, authors publish on their own web sites, and also deposit their articles, in draft or working paper series, for comments, before they are accepted for publication, in one of the two electronic repositories, SSRN Social Science Research Network, and BePress. Berkeley Electronic Press. ${ }^{41}$ Generally, law librarians can be advocates of greater open access to legal scholarship by educating authors, e.g. their faculty members, about the importance of retaining copyright, rather than assigning it to a journal, which creates barriers to the future distribution of their works. The Lewis \& Clark Law Library has created a web site full of useful information, ${ }^{42}$ based on a Symposium held at the Law School, on "Open Access Publishing and the Future of Legal Scholarship." ${ }^{43}$ Another site provides a directory of open access journals, including law

\footnotetext{
${ }^{39}$ Members' Briefing. Open Access by Paul George and the AALL Open Access Task Force 9 AALL Spectrum (April 2005 Center Insert). http://www.aallnet.org/products/pub_sp0504/pub_sp0504_MB

${ }^{40}$ Several law reviews now have introduced a blog-like online companion to their law review, that includes additional materials and commentary , e.g. Environmental Law Online (http://www.elawreview.org/elaw/), Yale Law Journal has Pocket Part (http://www.thepocketpart.org/), Harvard Law Review has The Forum (http://www.harvardlawreview.org/), Michigan Law Review has First Impressions (

<http://www.michiganlawreview.org/index-fi.htm), Northwestern University Law Review added Colloquy (http://northwestern-colloquy.typepad.com/), Texas Law Review has See Also

(http://www.texaslrev.com/seealso/), Virginia Law Review added In Brief

(http://virginialawreview.org/index.php), and University of Pennsylvania Law Revie has PENNumbra (http://www.pennumbra.com/).

${ }^{41}$ SSRN Legal Scholarship Network http://www.ssrn.com/lsn/index.html; BePress Legal Repository http://law.bepress.com/repository/

42 http://lawlib.lclark.edu/research/open_access/

43 “Symposium: Open Access Publishing and the Future of Legal Scholarship,” 10 Lewis \& Clark L. Rev. 733-924 (2006). Miller, Joseph Scott. “Foreword: Why Open Access to Scholarship Matters,” 733-739; Carroll, Michael W. The movement for open access law. 741-760;Hunter, Dan, “Open Access to Infinite Content (or "In Praise of Law Reviews")” 761-778. Litman, Jessica, “The Economics of Open Access Law Publishing” 779-795;Arewa, Olufunmilayo B.,’Open Access in a Closed Universe: Lexis, Westlaw, Law Schools, and the Legal Information Market” 797-839; Solum, Lawrence B.,’Download it While it's Hot: Open Access and Legal Scholarship” 841-867 (2006);Bartow, Ann,”Open Access, Law, Knowledge, Copyrights, Dominance and Subordination” 869-884 (2006); Bodie, Matthew T. "Open Access in Law
} 
journals. ${ }^{44}$ The AALL Members' Briefing on Open Access provides a summary of the issues and a progress report on accomplishments. ${ }^{45}$

\section{Mass Digitization Projects}

In the past several years, individuals, institutions, and commercial companies have engaged in the business of digitizing print collections. Focusing on U.S. legal scholarship, some of the larger commercial sets include U.S Supreme Court Records and Briefs, $1832-1978{ }^{46}$ and Making of Modern Law (MoML). ${ }^{47}$ These resources are extremely expensive, but quite valuable, and it is a one time expense, with long term access guarantee. HeinOnline is another major service, which contains most U.S. law reviews since their inception, in PDF, and fully searchable, as well as many other materials. ${ }^{48}$ Some universities have started institutional projects, for instance, Cornell Law Library is digitizing its large historical trials collection (U.S. and British) in collaboration with the Hein Publishing Company.

Mass digitization projects are by essence of a different nature than the digitization projects mentioned above. The ones often referred to are Google Book Project, and Microsoft Book project, ${ }^{49}$ which is done in cooperation with the Open Content Alliance (OCA), ${ }^{50}$ itself a pioneer in mass digitization. The OCA's masthead states the goal "to

Teaching: a New Approach to Legal Education” 885-898; Madison, Michael J. “The Idea of the Law Review: Scholarship, Prestige and Open Access” 901-924 .

${ }^{44}$ http://www.doaj.org/

${ }^{45}$ See supra footnote 39.

${ }^{46}$ http://www.gale.com/SupremeCourt/. Thomson Gale. The online, image-based, PDF collection can be searched or browsed, by case citation, docket number, party name, or keyword, or Boolean searching, or date.

${ }^{47}$ http://www.gale.com/ModernLaw/. Derived from the Nineteenth Century and Twentieth Century Legal Treatises microfilm collections, features a fully searchable digital database of nearly 22,000 full-text Anglo-American legal works including casebooks, local practice manuals, form books, works for lay readers, pamphlets, letters, speeches, and more. Subscribers can buy the cataloging records and have each individual title in the database is represented in their online catalog, with a direct link to the resource.

${ }^{48}$ www.heinonline.org. HeinOnline contains over 900 U.S. law reviews, image-based (PDF) and fullysearchable, providing exact page images, as they originally appeared in hardcopy, and including all charts, graphs, and photographs, which is not the case for Lexis or Westlaw (which provide coverage of fewer journals full-text from about 1980 to the present). In addition to the law reviews, HeinOnline provides an ever growing collection of materials on U.S.law, as well as foreign and international law.

${ }^{49}$ Microsoft is working with the OCA on this project. http://www.microsoft.com/presspass/press/2005/oct05/10-25MSNBookSearchPR.mspx

Barbara Quint, “Microsoft Launches Book Digitization Project-MSN Book Search ,” Info Today, posted On October 31, 2005 
build a digital archive of global content for universal access.” ${ }^{51}$ The Google Book Project is inspired by Google's philosophy, "to organize the world's information and make it universally accessible and useful.” ${ }^{52}$ It intends to scan every book ever published, and to make the full texts searchable. How many books are there? The most volumes listed in any catalogue is thirty-two million, the number in WorldCat. ${ }^{53}$ Google aims to scan at least that many within ten years. ${ }^{54}$ On Google Book Search, you can type in your search terms, and it will run through every page in its collection and provide you with a list of all the matches it can find. You can access information in ways unimaginable before. If still covered by copyright, Google will supply you with images of the lines containing your search terms, or perhaps even a whole page, together with links to booksellers and libraries that have the book. ${ }^{55}$

The World Digital Library is another project worth mentioning, because it is outside of the U.S. orbit. Launched in Dec. 2006, it is to make available on the Internet, free of charge and in multilingual format, significant primary materials from cultures around the world. ${ }^{56}$ The objectives of the World Digital Library are to promote international and inter-cultural understanding and awareness, expand non-English and non-Western content on the Internet, and to contribute to scholarly research. The National Library of Brazil is a world partner.

Virtual libraries have many advantages. They give instant access to highresolution images of every single page of thousands of rare old books and papers. They allow one to conduct instantaneous electronic searches covering every word within them. They combine the advantages of an exact photographic image with computer-searchable text.

\footnotetext{
${ }^{50}$ http://www.opencontentalliance.org/

${ }^{51}$ For an analysis of mass digitization projects, see Richard K. Johnson, "In Google’s Broad Wake: Taking Responsibility for Shaping the Global Digital Library,” ARL Special Report (Feb. 2007). http://www.arl.org/bm doc/arlbr250digprinciples.pdf

${ }^{52}$ www.books.google.com

${ }^{53}$ Jeffrey Toobin, “Google’s Moonshot: The Quest for the Universal Library.” New Yorker (Feb. 5, 2007). http://www.newyorker.com/fact/content/articles/070205fa_fact_toobin

${ }^{54}$ Rée, Jonathan, “The Library of Google,” Prospect (February 2007). http://www.prospect-magazine.co.uk/article_details.php?id=8215

${ }^{55} \underline{I d}$.

${ }^{56}$ http://www.worlddigitallibrary.org
} 


\section{Taking a Critical Look}

The rapidly evolving technological changes and ever expanding digital libraries have created a new set of problems unheard of in the print world, because of the different medium. These issues and concerns include: loss of research skills, preservation of born digital information, and authentication of official legal sources. Copyright issues are developing in the digital environment, and may impede the dissemination of scholarship, when open access would stimulate it.

\section{A. Impact of Internet on Legal Research}

In spite of the huge technological advances, access to information is different from use as a reliable source. There are both positives and negatives. A huge amount of information is accessible, in an easy and convenient way, but it is unfiltered, and on the web currently, there is no organized control of information, it is hard to know what you are missing, and if the information you find is accurate and authoritative, ${ }^{57}$ and the most relevant to your specific needs. Researchers want easy, convenient access to the most reliable materials that directly relate to their research interests, which is the reason library indexing and classification tools and systems have been designed in the first place, so that researchers have precision in their research. These tools are lost in full text searching. ${ }^{58}$ Full text online searching can yield a wealth of information. Often lacking is the proper context and direction to ensure the mass of information is highly relevant to the matter at hand. This problem can be met by resorting to web guides, or background texts online or in print, which provide analysis and summaries. ${ }^{59}$ In the law field in the United States, the reliance on Internet search engines has led to the loss of a lot of sophisticated indexing tools, such as subject and digest keyword indexing, the elaborate system created by West and used since the end of the 19th century. ${ }^{60}$ Many commentators have written on comparing free text searching versus classified arrangement and indexes. In general, free-text works best for factual research, but not always with the best results. Even Lexis came out with its own headnotes and classification several years ago, after starting as a pure full text database. Also, for the general public, there are some limitations to getting the plain text of the law. How much can one understand the law by looking at a text? If no context is provided, it may be harder to understand the issues, the procedure, etc., which are provided in a commercial

\footnotetext{
${ }^{57}$ See infra, Section C, on “Authenticity of Official Legal Digital Sources.”

${ }^{58}$ Richard Leiter, “Musings on the Future of Law Libraries ,” 26 legal information alert 7-8 (Jan. 2007).

${ }^{59}$ See examples at the end of this section.

${ }^{60}$ For a good history, see Robert Berring, "Legal Research and Legal Concepts: Where Form Molds Substance," 75 California Law Review 5 (1987). See also Richard A. Danner, "Legal Information and the Development of American Law: Writings on the Form and Structure of the Published Law" 99 Law Library Journal (forthcoming 2007).
} 
system such as West, with headnotes and annotations. The greatest danger is for non professionals who get the letter of the law, but not the context. The Internet makes legal information much more accessible to the public. But, it is not clear that the greater accessibility makes the law more understandable, because it may lack a context. People can misinterpret the text of the law, unless there are disclaimers. It may also put a greater burden on the legal profession to explain the law. So, what is there to do?

In evaluating a web source, the following questions need to be asked and answered with some confidence. What is the source? Is this source reliable? Is it up-todate? Is this the official, final version of a text? Can you cite this to a court? ${ }^{61}$ For research purposes, it is important to strike a balance between electronic and print sources, and know the strengths and weaknesses of each. ${ }^{62}$ To make some sense out of the mass of information provided on the Internet, a good way to manage legal information on the Internet is to start with reputable web sites. For the United States, here are a few good and free commercial sites: Findlaw, ${ }^{63}$ and LexisOne, ${ }^{64}$ are free comprehensive sites on U.S. law (respectively belonging to Westlaw and Lexis, the premium fee-based services), Law.com ${ }^{65}$ is a leading legal news and information network for attorneys and other legal professionals. LLRX ${ }^{66}$ is geared to legal information professionals. An efficient approach in dealing with information overload and unfiltered information while doing legal research, is to start with authoritative research guides on the web. The following have emerged as great starting points for legal research on a worldwide scope: Law Library of Congress Guide to Law Online, ${ }^{67}$ and the Global Legal Information Network (GLIN). ${ }^{68}$ the American Society of International Law web site has a Research part. ${ }^{69}$

\footnotetext{
${ }^{61}$ For some tips, see Doyle, Tony, \& John L. Hammond, "Net Cred: Evaluating the Internet as a Research Source," 34 Reference Services Review 56-70 (2006); Vaughan, C. Judd, Lucy I. Farrow, \& Betty J. Tims, "Evaluating Public Web Site Information: A Process and an Instrument," 34 Reference Services Review 12 32 (2006).

${ }^{62}$ Anne V. Ellis, “The Joy of Paper and Ink,” Legal Times (July 17, 2006). http://west.thomson.com/pdf/librarian/Ellis_Legal_Times071706.pdf

63 www.findlaw.com

${ }^{64}$ www.lexisone.com

${ }^{65}$ www.law.com

${ }^{66}$ http://www.llrx.com/

${ }^{67}$ Annotated guide covering U.S., international areas, and individual countries http://www.loc.gov/law/guide/index.html, The Guide to Law Online, prepared by the U.S. Law Library of Congress Public Services Division, is an annotated guide to sources of information on government and law available online. It includes selected links to useful and reliable sites for legal information. International and Multinational Nations of the World.

${ }^{68}$ Public database of laws, regulations, judicial decisions, and other complementary legal sources contributed by governmental agencies and international organizations http://www.glin.gov/
} 
Two services of note, which annotate new web sites of interest, and classify them, are INTUTE: Law $^{70}$ and InSite. ${ }^{71}$ An example of a collaborative search engine application is the new Cornell Law Library's new Legal Research Engine, which helps users find authoritative online legal research guides on every subject, by searching about twenty different web sites. ${ }^{72}$ Finally, two general indexes with full text links, Current Cites, ${ }^{73}$ and Resourceshelf, ${ }^{74}$ are useful current awareness tools, as well as First Monday. ${ }^{75}$

One of my favorite tools to find books by subject or keyword, in any language, is Worldcat. It is a wide ranging union catalog, and, since the summer of 2006, it became available for free searching by anyone. Its combined holdings of thousands of libraries worldwide make it particularly valuable. It includes all 70-plus million records in the database, with an easy-to-use interface. ${ }^{76}$ So, if you want to find books in English on French Law starting with the most recent ones, you can limit your search by language and date.

\footnotetext{
${ }^{69}$ http://www.asil.org/resources/index.html. An excellent guide to authoritative web sites and helpful research guides to international law on the Internet, including a database, Electronic Information System for International Law (EISIL).

${ }^{70}$ http://www.intute.ac.uk/socialsciences/law/. The service identifies and evaluates legal resource sites offering primary and secondary materials and other items of legal interest.

${ }^{71}$ http://library.lawschool.cornell.edu/RESOURCES/insite.htm. The service annotates new law related web sites.

72 The twenty different web sites either publish guides, or index and link to guides. http://library.lawschool.cornell.edu/guides/researchengine.asp

${ }^{73}$ www.lists.webjunction.org/currentcites. A monthly selection of annotated citations of current literature in information technology.

${ }^{74}$ http://www.resourceshelf.com. A web site run by librarians who find useful resources.

${ }^{75}$ http://www.firstmonday.org/. Peer reviewed journal on the Internet.

${ }^{76}$ WorldCat.org
} 


\section{B. Preservation of Born Digital Information ${ }^{77}$}

In various countries of the world, official documents are going digital for good reasons, including easy distribution and access over the Internet, and cost savings for government which can discontinue the print costs. The process is irreversible politically and economically. However, digital information is characterized by fragility and rapid technological obsolescence. Under good conditions, books printed on acid-free paper, e.g., official state reports and codes, will last for centuries. The lifespan of a CD or disk is estimated at 10 to 30 years, but its lifespan is further limited by the hardware and software needed to read it. This means that digital information may become obsolete within five years unless it can be refreshed or migrated to a newer technology. Refreshing data (copying it periodically to more stable media) cannot solve the long-term problem. It can save simple ASCII files, but anything more complex may lose functionality that was built into it. Migration means moving files to a new system. It has risks, too, such as loss or change of information in the translation. Emulation consists of designing hardware and software that emulate the old system. Much research needs to be done on solving these technological issues. ${ }^{78}$ The problem is particularly acute for "born digital" information, which has no print equivalent, because it was created online. A checklist of digital certification criteria applicable to a range of digital repositories and archives has been developed by RLG (Research Libraries Group) and CRL (Center for Research Libraries), to identify digital repositories capable of reliably storing, migrating, and providing access to digital collections. ${ }^{79}$ Other efforts include Portico, an electronic archiving system of scholarly literature, including journals. ${ }^{80}$

\footnotetext{
${ }^{76}$ I have been involved in that issue for many years, having served as Chair, AALL/Library of Congress Task Force on Preservation of Digital Law, in 1998-1999, on AALL's Special Committee on Authentication and Preservation of Digital Law, in 1999-2001, and organized a Summit meeting in Ithaca, N.Y., in the Summer of 1998, with Dr. Rubens Medina, Law Librarian of Congress. "The Future of Legal Documents," Library of Congress Official Bulletin (October 1998) http://www.loc.gov/loc/lcib/9810/law.html. For current information on efforts in the U.S., see Membership Briefing, Preservation, by The Special Committee on Permanent Public Access to Legal Information, chaired by Judy Meadows, Montana State Law Librarian, 10 AALL Spectrum (Dec. 2005 Center Insert). http://www.aallnet.org/products/pub_sp0512/pub_sp0512_MB

78 "Legal Information on the Internet: U.S. Perspectives," (Paris, Oct. 1998, French Association for the Development of Legal Informatics) (ADIJ, Association pour le developpement de l'informatique juridique). Available at www.lawschool.cornell.edu/

${ }^{79}$ Called TRAC (a Trustworthy Repositories Audit and Certification Checklist), it is the result of the experience and knowledge of various digital repositories in the U.S.A. and Europe, including the E-Depot at the Koninklijke Bibliotheek in the Netherlands, the Inter-University Consortium for Political and Social Research, Portico, the Digital Curation Center (U.K.), DigitalPreservationEurope (Continental Europe) and NESTOR (Germany). The 93-page report is available in pdf from the Center for Research Libraries http://bibpurl.oclc.org/web/16712

${ }^{80}$ http://www.portico.org/. Anne Kenney, Interim University Librarian, Cornell University Library, serves on the Advisory Committee of Portico, and is a world renown expert in digital preservation, having written extensively and taught tutorials in this area.
} 
Beyond the technical problems related to the fragility of the digital medium, there are a number of financial, legal, and policy issues at stake with digital legal information. Who will decide what to preserve? Who will pay for preserving digital information? Who is going to be responsible for continued and long-term access to authoritative digital primary legal information sources? This is especially important in a democracy where free access to government information is supposed to be a right. It is assumed here that most primary legal information, at least in the US, is in the public domain. However, copyright may be an issue for some digital records in the US and for many sources abroad because of different governmental policies.

The contents of the Internet are becoming richer every day. One issue of particular importance that has emerged now is the need to have access to the permanent digital records far into the future. Current efforts have the same goal, to make sure that in a paperless world there will be a permanent record of the law in its many forms, and that the document will be authentic. They demonstrate the importance to work with partners on joint problem solving, including the legal information publishing industry, the information technology industry, computer scientists, and other interested stakeholders.

Two web sites offer promise in this area. The web archive, Wayback machine, ${ }^{81}$ the mission of which is to archive the web for future generations. It is free, but offers a new service, Archive-It 2.0, a subscription-based archiving service geared towards a broad range of institutions, and enables subscribers to capture, catalog, and preserve online material from their own institutions as well as from the world wide web.

WebCite ${ }^{82}$ is an archiving system for web references, which can be used by authors, editors, and publishers of scholarly papers and books, to ensure that cited web content will remain available to readers in the future. If cited web references in journal articles, books etc. are not archived, future readers may encounter a "404 File Not Found" error when clicking on a cited URL. A WebCite ${ }^{\circledR}$ reference is an archived web citation, and rather than linking to the live website (which can and probably will disappear in the future), authors of scholarly works will link to the archived WebCite ${ }^{\circledR}$ copy on webcitation.org. This particular archiving system may offer some hope to the many who lament the fact that courts and others (law reviews, etc.) cite to URLs which no longer exist. $^{83}$

\footnotetext{
${ }^{81}$ www.webarchive.org

${ }^{82}$ www.webcitation.org

${ }^{83}$ George Nicholson, Associate Justice, California Supreme Court, talked about the problem at the 2005 AALL meeting in San Antonio, at a presentation called "The Great Disappearing Act; Preserving URLs Cited in Judicial Opinions.” Audiotape available. Summary at MALL Newsletter 16-17 (August 2005). http://www.aallnet.org/chapter/mall/news321.pdf
} 


\section{Authenticity of Official Legal Digital Sources}

In Brazil, the texts of legal rules available on the Internet have only an informative nature. They must have been previously published in the Official Gazettes. ${ }^{84}$ In France, the Journal Officiel electronic version has been authenticated since 2004 legislation. ${ }^{85}$ Why is this issue important? It is because in every country of the world, in an environment where online sources have replaced official print legal information, citizens need to trust the "official word of the law, " in the same way that they trust the print information. Since the digital medium is vulnerable to errors in management and control, corruption, and tampering, it is therefore of utmost importance to make the digital information both official and authentic. What is at stake is the transmission of official documents, "the word of the law," to future generations. ${ }^{86}$

In the United States, the American Association of Law Libraries (AALL) has been very active in surveying progress in the fifty states. During my Presidency, I commissioned an AALL Fifty State Survey on official and authentic digital legal information. AALL's 2006 Authentication Survey investigated six sources of law: state statutes and session laws, state high and intermediate appellate court opinions, and state administrative codes and registers. For each legal document, the question was: is the digital version considered official? Is it considered authentic? The summary results show that a significant number of the state online legal resources are official, but none are authenticated by standard methods.

What is the difference between "official" and "authentic"? The definition of an online official legal resource is one that possesses the same status as a print official legal resource. The definition of an official version of court opinions, statutes, session laws, or regulatory materials is one "that has been governmentally mandated or approved by statute or rule. It might be produced by the government, but does not have to be." ${ }^{87}$ This definition is firmly rooted in the print world. Courts and public officials turn to official

\footnotetext{
${ }^{84}$ Edilenice Passos, “Doing Legal Research in Brazil,“Feb. 2005. http://www.nyulawglobal.org/globalex/Brazil.htm

${ }^{85}$ http://www.journal-officiel.gouv.fr/

${ }^{86}$ Claire M. Germain, "Digital Legal Information: Ensuring Access to the 'Official' Word of the Law," 26 Cornell Law Forum 11-14 (1999); "Digital Legal Information: Here Today, Gone Tomorrow?," Syllabus (ABA) 17 (Spring 1998).

${ }^{87}$ See Authentication Survey Executive Summary. http://www.aallnet.org/aallwash/authen_rprt/ExecutiveSummaryReport.pdf The definition is drawn from the latest editions of Black's Law Dictionary and Fundamentals of Legal Research (by J. Myron Jacobstein, Roy M. Mersky, \& Donald J. Dunn) and adopted as a guide to survey participants.
} 
legal resources for authoritative and reliable statements of the law and require citation to such sources in the documents that come before them. An online official legal resource offers no such automatic assurance.

The definition of an online authentic legal resource is one whose content has been verified by a government entity to be complete and unaltered when compared to the version approved or published by the content originator. Typically, an authentic text will bear a certificate or mark that conveys information as to its certification, so that the text is authenticated. The standard methods of authentication include encryption, especially digital signatures and public key infrastructure, or similar technologies. ${ }^{88}$

The AALL's Authentication Report raises concerns that must be addressed by the states, both as high-level policy decisions and practical matters. AALL believes that the Authentication Report will serve as a guide for states to correct smaller-scale deficiencies in their current dissemination of online legal resources and to initiate long-term progress toward the all-digital legal information environment that will enhance each state's fundamental interaction with its citizens. ${ }^{89}$ To help foster changes, AALL, under Sally Holterhoff's presidency, convened Authentic Legal Information in the Digital Age: A National Summit to discuss these issues with the major key stakeholders, on April 20-21, 2007. Approximately fifty delegates from the judiciary, the legal community, state governments, and interested organizations, all of whom share AALL's concern about ensuring the authenticity of digital legal information, participated in discussions about the Authentication Report and explored legal and technological solutions to ensure that state online legal resources are authenticated and trustworthy. In the U.S., at the federal level, the U.S. Government Printing Office is moving rapidly toward a digital system to replace print government documents ${ }^{90}$ The G.P.O. Future Digital System (FDsys) is to automate the collection and dissemination of electronic information from all three branches of

\footnotetext{
88 A Public Key Infrastructure (PKI) is "an asymmetric cryptography security environment that supports the transmission, delivery, and receipt of digital communications over a non-secure communications channel. PKI uses a pair of cryptographically related keys known as public and private keys which verify the identity of the sender (signing) and/or ensure privacy (encryption)." Information provided by Mike Wash, Chief Technical Officer, U.S. Government Printing Office. For further reading, see Public Key Infrastructure Assessment Guidelines, American Bar Association, Electronic Commerce and Information Technology Division, Information Security Committee (2003). ${ }^{89}$ Id.

90 See The Authentication White Paper and the Version Control White Paper, prepared by the U.S. Government Printing Office in 2005. The Authentication White Paper addresses planning and implementation issues related to authentication of electronic content. http://www.access.gpo.gov/su_docs/fdlp/pubs/proceedings/05spring/cdqa/authentication_white_paper.pdf. The Version Control White Paper addresses planning and implementation issues related to version control of electronic content within the scope of the Federal Depository Library Program (FDLP). http://www.access.gpo.gov/su_docs/fdlp/pubs/proceedings/05spring/cdqa/version_control_white_paper.pdf For an earlier commentary, see "Le projet GPO visant à conserver l'ensemble des données juridiques publiques américaines," Cornell Law School Working Paper Series, Paper 17 (November 2004). http://lsr.nellco.org/cornell/clsops/papers/17/
} 
government (executive, legislative, and judicial). Information will be permanently available in electronic format, authenticated, with version control, and accessible via the web for searching, viewing, downloading, and printing. The first public release of FDsys is scheduled for December $2007 .^{91}$

AALL's philosophy is to help ensure access to the permanent digital records far into the future; to make sure that in a paperless world there will be a permanent record of the law in its many forms, and that the document will be authentic.

\section{New Roles for Librarians in the Digital Age}

In this rapidly evolving technological environment, and in the face of constant change, what are the new roles for librarians? Technology does not replace human expertise, and law librarians are called upon to provide guidance in a pro active way, reaching out to their audience, since the audience may not go to them. The focus here is on law librarians, not libraries. But a few thoughts are in order first on the future of law libraries. Even though their demise has been proclaimed many times, it may be based on the erroneous assumption that libraries are warehouses of books. Libraries are physical buildings that house library materials, but they do so in an organized fashion, and providing classified access to library materials. ${ }^{92}$ A library in its fullest sense is more than a building, it is a place where people are served and where people are not only encouraged to interact with the information they are seeking, but are helped and guided in their research. ${ }^{93}$ How then will law librarians cope with the information overflow and provide guidance in a way that meets the needs of researchers, whether they come to the physical library, or directly through the library web site, or other distant technologies? New roles emerge for librarians who are needed to evaluate the quality of information; teach legal research methodology; and be seen as core participants in the mission of their institutions. This is a tall order, because at the same time they need to keep up with the breakneck pace of technology, and adjust to the new information seeking and usage behaviors of students, faculty, judges and lawyers.

\section{A. Librarians as Experts in Quality Evaluation}

While the Internet provides much useful information, the information is not necessarily relevant or even correct. It is up to law librarians, to ensure that accuracy and authenticity matters, by telling each researcher with confidence: "This is the information you need, this is the information from a reliable source, and it will be here for you a year

\footnotetext{
${ }^{91}$ Information provided by Mike Wash, Chief Technical Officer, U.S. Government Printing Office, at the AALL Authentication Summit, Chicago, April 20-21, 2007. See also http://www.gpo.gov/projects/fdsys.htm

${ }^{92}$ Richard Leiter, “Musings on the Future of Law Libraries ,” 26 legal information alert 7 (Jan. 2007).

${ }^{93}$ Id.
} 
from now." ${ }^{94}$ The expansion of a popular expression in the United States is that law librarians provide the "good housekeeping seal of approval" for quality information. ${ }^{95} \mathrm{At}$ the Centennial celebration of AALL, in St Louis, Missouri, in July 2006, Bob Berring challenged law librarians to navigate a constantly changing legal information landscape by relying on the core values established by the founders of AALL 100 years ago. Looking back at the beginnings of AALL, Professor Berring reminded his listeners of the problems facing law librarians at the first Annual Meeting in 1906: gathering materials, organizing them, and, in the words of A.J. Small, the first AALL president, "guaranteeing high quality information to the people that need it." Berring continued that "such "problems" are precisely the ones we deal with today. ${ }^{96}$ Stephen Abram, ${ }^{97}$ refers to the new breed of librarian, "Librarian 2.0," as the guru of the information age,"98 another apt way to describe the role of librarians.

\section{B. Librarians as Teachers of Legal Research}

A particular new role for librarians is teaching, the special niche of legal research instruction, in the court, law firm, or law school, in a formal, or one-on-one capacity. In this age of technologies, there are many new information providers that compete with librarians. Finding information and doing research effectively require different sets of competencies. Law librarians are the true legal research experts. They know how to find reliable and authentic legal information. They are methodical in finding the specific information that their faculty, students, judges, or lawyers need. The 2006 AALL Members' Briefing on Legal Research provides many examples and advice on teaching legal research in different institutional settings. ${ }^{99}$ During my year as President of AALL,

\footnotetext{
${ }^{94}$ Freely adapted from a remark made by Robert (Bob) Berring, Jr., the Walter Perry Johnson Professor of Law at the University of California, Berkeley, at a keynote address at the AALL Centennial meeting in St Louis, Missouri, in July 2006. Bob Berring was director of the law library at Berkeley from 1982 to 2005.

95 The expression of "good housekeeping seal of approval” was coined by Dr. Harvey Washington Wiley, a professor of chemistry, who is credited for the passage of the Pure Food and Drugs Law in 1906 and served as the first commissioner of what would later become the Food and Drug Administration. In 1912, he took over the laboratories for the Good Housekeeping Magazine, and established the Good Housekeeping Seal of Approval, still in use today, for well designed products and appliances. http://thomas.loc.gov/cgi-bin/cpquery/R?cp107:FLD010:@1(hr429). The term is now used for many other examples of quality product.

${ }^{96}$ Summary provided by Matt Braun in ALL-SIS Newsletter (Fall 2006) at http://www.aallnet.org/sis/allsis/newsletter/26_1/Berring.htm

${ }^{97}$ Stephen Abram often writes on future-oriented topics, and is Vice President of Innovation at SirsiDynix, and President Elect of SLA.

${ }^{98}$ Stephen Abram, "Web 2.0, Library 2.0, and Librarian 2.0: Preparing for the 2.0 World," 2 SirsiDynix OneSource (January 2006). http://www.imakenews.com/sirsi/e article000505688.cfm

${ }^{99}$ A Special AALL Committee on Legal Research, chaired by Blair Kauffman, Librarian and Professor of Law, Yale Law School, focused on enhancing the value of law librarians as the information experts in their institutions, whether law firms, academic, corporate, or government settings, fostering the expertise of law
} 
these efforts took an even more exciting turn, as Erica Moeser, the President of the U.S. National Conference of Bar Examiners, invited a number of AALL members to meet in Madison, Wisconsin, in June 2006, with testing experts, to discuss various issues relating to testing legal research skills on the bar exam. 100

In this day of globalization, it is important to develop expertise in international and foreign law, in addition to one's own legal system, and not assume knowledge from similar sounding concepts. ${ }^{101}$ There are major differences in the form of the law and the way it is arranged, i.e., the structure of the legal system, the divisions of the law, and its classification. These differences are important because the problem that confronts a researcher is which terms to use to look up the foreign law, whether it is on the Internet, or in books and indexes. Among the legal traditions, the civil law system is prevailing in most of continental Europe, and often contrasted with the common law system, elaborated by the Royal courts of England in medieval times. One also needs to study the social, economic, and political background of a foreign legal system before being able to understand its rules and institutions. It matters whether a country is federal or unitary. There is often an absence of exact correspondence between legal concepts and categories in different legal systems. Concepts such as force majeure, faute, consideration, cause, and the Conseil d'Etat, cannot be understood without a deeper knowledge of the legal system of the country studied. Translating the Conseil d'Etat simply as Council of State is not very meaningful if one ignores the fact that the Conseil d'Etat serves both as a counseling body to the government (drafting bills) and as the highest administrative court in France, and that, more importantly, in France and several other civil law countries, the government and its employees, at the national, regional, and local levels, cannot be sued in ordinary courts, but only in administrative courts (which are very different from the administrative courts in a country like the U.S.A.). ${ }^{102}$ The explanation of the concept of "notary" is yet another example of misleading synonyms, faux amis. In civil law countries, the notaire (French; Notar in German) is a highly trained legal professional with a law degree and a specialized training similar to the one required of judges or attorneys. The question that arises in U.S. courts is to what extent a U.S. notary can certify a document for a German corporation. Most German courts will not recognize their authority, because the professions are totally different, even though the titles sound

librarians providing a core competency for their institutions; and promoting the teaching role of the law librarian as faculty member in the law school, or equivalent--instructor, trainer-- in law firms, courts, and other law library settings. The Special Committee on Legal Research published a Members' Briefing in AALL Spectrum (July 2006 Center Insert) http://www.aallnet.org/products/pub_sp0607/pub_sp0607_MB.pdf

\footnotetext{
${ }^{100}$ This initiative was the result of a team effort, involving Professor Roy Mersky, University of Texas law School, President Erica Moeser's strong interest and vision, and the active participation of several law librarians and AALL support.

${ }^{101}$ This section draws on information provided in Germain's Transnational Law Research, Ch. II, especially Sections 2.06-2.08.

${ }^{102}$ See Germain’s Transnational law Research, Ch. II, Section 2.08.1.
} 
similar. Translation poses its own perils. Translation machines like Alta Vista are appealing because they propose an easy looking solution to the perennial problem of Babel. However, they can only be a starting point, and be dealt with very cautiously. ${ }^{103}$ Even when there is a real translator, it is essential to understand the cultural context of legal language, and there is a need for better training of legal translators, better glossaries and standardized legal terms. ${ }^{104}$

\section{Librarians as Core Participants in the Mission of their Institutions}

For librarians to perform their role most effectively, they need to be considered as core participants in the mission of their institutions. In a digital environment, they now have to be pro active and reach out to their users in the communities where they work, rather than waiting to be asked. One cannot be effective without being visible. Promoting the visibility of librarians has been a particular focus of AALL in recent years, as documented in the 2006 Members' Briefing which comes up with measurable methods of success in reaching out to the legal community. ${ }^{105}$ The AALL's Publishing Initiatives Caucus (PIC) encourages librarians to write for legal publications, and maintains a growing web site with links which encourage other librarians to do the same. ${ }^{106}$

\section{Advocates for Free Access through Global Networks}

There is a strong network of law library associations throughout the world, ${ }^{107}$ and of course, our own International Association of Law Libraries, plays a key role in bringing law librarians from different countries together. ${ }^{108}$ The benefits of international meetings are numerous. Personal contacts are formed, that lead to various communications and exchanges. Recently, a European law librarian told me that he had been inspired by U.S. law librarians to write his own book on law research in his country. We can also learn from what law librarians in other countries are doing. I learned most of what I know about Web 2.0 after attending a well organized Workshop on "Legal

\footnotetext{
${ }^{103}$ For some good pointers, see Sarah Yates, "I Need This in English,” 9 AALL Spectrum (April 2005), pointing out with examples that Web translators are useful tools to find context, but not precise translations.

${ }^{104}$ See Germain’s Transnational Law Research, Ch. II, Section 208.3

105 The Special AALL Committee on Promoting Law Librarians to the Legal Community, chaired by Gail Warren, State Law Librarian, Virginia State Law Library, focused on promoting the visibility of librarians, and stressed the importance of working closely with the legal profession and law-related associations, and communicate their value effectively to the practicing bar, judiciary, the media, and law school deans. "Promoting Libraries," 10 AALL Spectrum (April 2006 Center Insert). http://www.aall.org/products/pub_sp0604/pub_sp0604_MB.pdf

${ }^{106}$ For more information, see http://www.aallnet.org/caucus/pic/index.htm

${ }^{107}$ See Listing of International, Regional, and National Law Library Associations at www.iall.org, and with thanks to Lyonette Louis Jacques, Foreign Law Librarian \& Lecturer, University of Chicago Law School, who created it and keeps it up-to-date, as well as a very useful Calendar of Events.

${ }^{108}$ www.iall.org
} 
Internet 2.0” in Paris in November 2006, organized by Juriconnexion. ${ }^{109}$ A Law Libraries Section has recently been established within the International Federation of Library Associations (IFLA,) and it is hoped that many law libraries will join it and that it will become a force within IFLA. ${ }^{110}$

Why is international networking useful? It allows librarians to have a voice in shaping their own future in an increasingly globalized world of information and services. It provides current and future opportunities to make international contacts and opportunities. It provides a potential network of contacts to help retrieve difficult to find legal materials and research assistance, as well as controlled vocabulary and technical know-how. It provides forums to advocate positions of interest to law librarians on a worldwide basis. It positions the associations to seek grants with national and international agencies and organizations, and seek corporate support. Continuing Professional Education Programs are also needed for continuous training, to keep skills sharp, as well as distance learning programs for librarians who cannot go to meetings. ${ }^{111}$ Finally, internships are a great way to exchange information and learn about different practices of law librarianship. ${ }^{112}$

Law librarians can get involved in advocacy efforts, and effect changes. They can act individually, at the grass root level, and as a group, through the advocacy of their national association. AALL has a strong focus on advocacy, and sets out in its strategic directions that law librarians will influence the outcome of legal information, technology policy, and librarianship issues of concern to AALL members. The very active Washington Affairs office works tirelessly to represent the interests of its members. ${ }^{113}$ A national law library association's actions are most effective when combined with those of other professional associations. Several international organizations, such as UNESCO and WIPO, recognize IFLA as the preferred speaker on matters of international policy that impact librarians and users. This speaks to IFLA's growing influence on the shaping of information policies.

\footnotetext{
109 http://www.juriconnexion.fr/

110 www.ifla.org
}

111 AALL has started a new continuing professional education program, which will include a distant learning component, and make use of new technologies when appropriate for its members. It has also committed financial resources to helping CPE programs at the regional and state level.

http://www.aall.org/prodev/

\footnotetext{
112 The Institute on Advanced Legal Studies in London has a regular program of internships. http://www.ials.sas.ac.uk/fellows/lfellows.htm, as well as the Max Planck Institute. See Claire M. Germain, "The Librarian Fellowship Program at the Max-Planck-Institute for Foreign and International Private Law in Hamburg, West Germany," 8 International Journal of Law Libraries 223-24 (1980).

113 http://www.aallnet.org/aallwash/
} 


\section{CONCLUSION}

Information reliability, authenticity, precision, relevance, accuracy, version control. The challenges posed by digital libraries are many. The long term consequences of the digital world are unknown. There is so much information available, but without any context, which raises educational issues. In the law field, it is not only a matter of digital competence, but also of legal consequence. Some as yet unanswered questions are whose responsibility is it to train the public, and whether there will a growing demand. The recent development in the U.S., to add a legal research test on the bar exam, is of interest to the whole world, because it signifies the importance of a sound legal research training to the competent practice of law. It is an amazing time to be a law librarian, and an information specialist. It is also an amazing time to be able to connect with so many colleagues from all over the world, and help one another. It makes us stronger as a profession, and more effective in communicating our value to the decision-makers in our institutions. What greater pleasure than to share what we know to foster knowledge and scholarship, and be both a great fan of innovation, and a guardian of digital records for the long term future. It is possible to embrace the information revolution, while keeping the tradition of service and quality of information that has been the trademark of libraries. 